\title{
Mind Maps as a Lifelong Learning Tool
}

\author{
Aliye Erdem \\ Department of Primary Education, Faculty of Educational Sciences, Ankara University, Turkey
}

Copyright $\bigcirc 2017$ by authors, all rights reserved. Authors agree that this article remains permanently open access under the terms of the Creative Commons Attribution License 4.0 International License

\begin{abstract}
Mind map, which was developed by Tony Buzan as a note-taking technique, is an application which has the power of uncovering the thoughts which the brain has about a subject from different viewpoints and which activate the right and left lobes of the brain together as an alternative to linear thought. It is known that mind maps have benefits such as recalling, improving the creativity, solving problem, focusing on a subject and organizing the thoughts. It is considered that mind maps have an important place as a lifelong learning tool nowadays when constructivist approach is used as base in the learning-teaching process. From this consideration forth, the objective of this study is to determine the opinions of university students with respect to using of mind maps and developing processes in preparing mind maps. This study was conducted according to interview technique which is among qualitative research methods. A total of 31 students who attend to five different licence programmes at Ankara University Faculty of Educational Sciences in fall semester of 2016-2017 academic year constitute the work group of the study. Semi-structured interview form which was developed by the researcher was used as data collection tool in the study. Data was analysed and interpreted by content analysis technique.
\end{abstract}

Keywords Mind Maps, Learning-Teaching Process, Lifelong Learning

\section{Introduction}

According to constructivist approach, learning is the process of individual linking up between his/her information. Individual uses the information recorded to his/her brain while forming the links. Human brain consists of two basic parts as the right and left lobe. Activities conducted by each lobe are different. While left lobe is responsible from logic, words, arithmetic, linearity, lines, lists and analyses; left lobe takes on the tasks such as spatial awareness, imagination, emotion, colour, rhythm, shapes, geometry and synthesis (Buzan, 2005). According to Townsend (1998, p. 94), it is required both lobes to be utilized in coordination in order to ensure learning properly. Learning actualise with the whole brain and brain prefers collaboration to conflict (Healy, 1997, p.45). Hence, both lobes of the brain are effective in learning.

As well as two lobes of human brain have different tasks, these two lobes do not perform separately. Because they must cooperate in order to display efficient performance. The more two sides of the brain operate at the same time, the more brain considers very well, stores lots of things and recalls faster (Buzan, 2009b). Mind maps were developed as a technique which was designed likewise the operation of the brain by using its right and left lobes together and which enables the ideas being reflected on paper.

Mind maps were developed by English psychologist, mathematician and brain researcher Tony Buzan at the late 1960s. Buzan and Buzan (2007) who make studies on note taking state that notes must have four main functions as being reminiscent, analysing, creative and interactive. Mind maps are a note taking technique which supports all of these functions.

Mind map which Buzan developed as a note taking technique is a technique which uncover the potential of the brain (Brinkmann, 2003), which information is stored, arranged and organized in order of priorities by using keywords and key concepts (Buzan, 2009a). According to Michalko (2001), mind map is a technique which has the power of uncovering the thoughts which the brain has about a subject from different viewpoints and which the brain is operated as a whole as an alternative to linear thought. And Kokotovich (2008) expressed mind map as a note taking technique which people put their ideas and thoughts on paper excursively.

Buzan (2005) emphasizes four important features of mind map as:

- Attention to subject is provided by a picture at the center of the mind map.

- Main themes of the subject are formed thanks to the branches related with the picture at the center.

- Branches state a key picture or keyword on the connected lines.

- Branches have a structure which is related to each other. 
In the relevant literature there are opinions about mind maps which state that they have benefits such as; recall (Holland, Holland and Davies, 2004; Brinkmann, 2003; Buzan and Buzan, 2007), improving creativity Buzan and Buzan, 2007; Mento, Martinelli and Jones, 1999; Cryer, 2006), problem solving and focusing on a subject (Buzan, 2005), organizing and arranging thoughts (Buzan and Buzan, 2007; Buzan, 2005). Besides it is expressed that while considered within the frame of constructive approach, mind maps is a visual tool which can be used in determining the preliminary information, thoughts, comprehensions, cognitive structures and conceptual relations of students and in the improvement of conceptual understanding (Goodnough and Woods, 2006; Brinkmann, 2003; Zhao, 2003; Goodnough and Long, 2006; Abi-El-Mona and Adb-El-Khalick, 2008), in encouragement of active learning (Wickramasinghe and others, 2008) and in associating the present information with the new information (Brinkmann, 2003).

Mind maps are an organized brain storm method (Michalko, 2001). Mind map is a strong graphical technique which targets to utilize the brain with its full capacity (Buzan and Buzan, 2007). Since the simultaneous usage of words and symbols activates the imagination as well, creativity also increases along with the consideration skills (Anderson, 1993; Margulies, 1991; Mento, Martinelli and Raymond, 1999; Tetzeli, 1992).

Brain map focuses on using almost all of the features of brain, namely it models our brain whose left lobe operates with words and right lobe with images. For brain, mind maps which are multi coloured, multi-dimensional and which provide stimulation visually are more attracting than one coloured traditional notes and also more effective in remembrance. Mind map functions in accord with the natural structure of brain. Similarity between natural arrangement of brain and mind map are shown at Figure 1.

Mind maps are used widely in every field in our day. Wycoff (1991) lists some of these usage fields as writing, project organization, brain storm, meetings, list making, presentations, note taking and self-improvement. Mind map along with being used at any stage of consideration process such as forming of individual and collective ideas, organization of these ideas and planning how to use them, it can be used in almost any field from taking note to convert a personal shopping list to a strategical scrutinizing (quoting from, Bütüner, 2006).

Mind maps may be used as an effective technique in the process of learning-teaching as a form of note taking which has significant differences from traditional note taking form, facilitate remembrance with its colorful structure with links on the basis of actively using of both lobes of the brain, convenient for constructivist learning. With reference to this consideration, the objective of this study is to determine the opinions of university students related to using mind maps and their developing processes in preparing mind map.

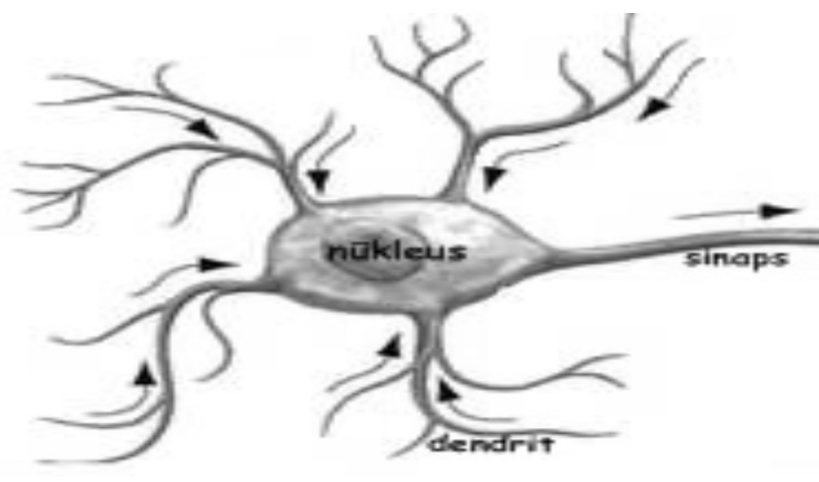

Brain cell (neuron)

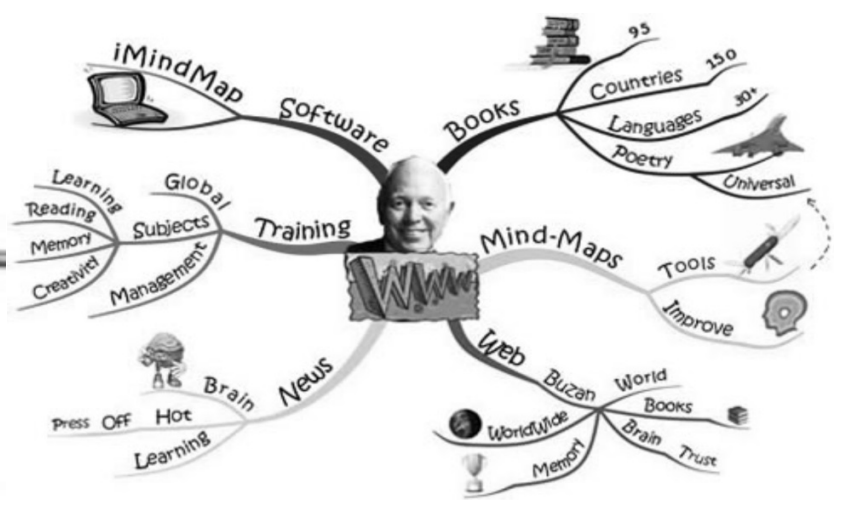

Mind map

Figure 1. Similarity between Brain Cells and Mind Map 


\section{Method}

\section{Model of the Study}

This study was conducted according to interview technique which is among qualitative research methods. Qualitative research methods, on the contrary of what is emphasized in quantitive researches, pay attention to uncovering relations enabling explanation and considering the situation covering the events and phenomena rather than measuring (Yıldırım and Şimşek, 2006). Interview is the data collecting (interrogation) technique by means of oral communication (Karasar, 2004). Interview is a form which interviewer poses questions to subjects on condition that being orally and generally face to face in order to take answer (Tavukçuoğlu, 2002). Interview is the controlled and purposeful oral communication form which takes place between the interviewer and the person at the position of the subject of the research (Cohen and Manion, 1994, p.271). According to the model of the interview, it is tried to enter the inner world of the one who is being interviewed and understand and comprehend the events from their perspective (Patton, 1987, p.109). Thus, people' own experiences should be understood much better from their languages, interpretations and explanations. Besides, the most basically way of learning how people construct and form the social reality on their minds is to ask people themselves as well. (Jones, 1985).

\section{Study Group}

A total of 31 students who attend to five different licence programmes at Ankara University Faculty of Educational Sciences in fall semester of 2016-2017 academic year constitute the work group of the study. Distribution of students participating in the study by gender is given in Table 1.

Table 1. Distribution of the Students by Gender

\begin{tabular}{|c|c|c|}
\hline Gender & f & $\mathbf{\%}$ \\
\hline Female & 28 & 90 \\
\hline Male & 3 & 10 \\
\hline TOTAL & $\mathbf{3 1}$ & $\mathbf{1 0 0}$ \\
\hline
\end{tabular}

As seen in Table 1, female students constitute the great majority of the students participating in the study. Distribution of students participating in the study by the programme they attend is given in Table 2 .

Table 2. Distribution of the Students by the Programme They Attend

\begin{tabular}{|l|c|c|}
\hline Programme They Attend & f & $\mathbf{\%}$ \\
\hline Psychological Counseling and Guidance ve Rehberlik & 18 & 58 \\
\hline Mentally Handicapped Teaching & 5 & 16 \\
\hline Preschool Teaching & 4 & 13 \\
\hline Computer and Instructional Technologies Eğitimi & 2 & 6.5 \\
\hline Social Sciences Teaching & 2 & 6.5 \\
\hline TOTAL & $\mathbf{3 1}$ & $\mathbf{1 0 0}$ \\
\hline
\end{tabular}

As seen in Table 2, the great majority of the students participating in the study attend to the programme of Psychological Counseling and Guidance. Distribution of students participating in the study by grades is given in Table 3.

Table 3. Distribution of students by grades

\begin{tabular}{|c|c|c|}
\hline Grade & f & $\mathbf{\%}$ \\
\hline 2. grade & 6 & 19 \\
\hline 3. grade & 12 & 39 \\
\hline 4. grade & 13 & 42 \\
\hline TOTAL & $\mathbf{3 1}$ & $\mathbf{1 0 0}$ \\
\hline
\end{tabular}

As seen in Table 3, the students participating in the study constitute of the students who attend to 4., 3. and 2. grades.

\section{Data Collection Tool, Collection and Analysis of Data}

Data of the study was obtained at the end of the activities conducted within the scope of the elective course named "Mind Map Applications" which was given at Ankara University Faculty of Educational Sciences in fall semester of 2016-2017 academic year. At the stage of the application of the study, students electing the course were informed about the application of the mind map technique and mind map samples related to different subjects were demonstrated to students. Afterwards, it was ensured that students prepare mind maps about different subjects during the term and discussions were made about the prepared mind maps as group.

As data collection tool in the study, semi-structured interview form which was developed by the researcher was used. Semi-structured interview questions which were prepared in order to determine the opinions of the students related to the usage of mind map technique were presented to the expert's opinion and the required amendments were performed. While the interviews were conducted individually, it was tried to prevent data loss by using tape recorder. Later on, the interview records were transcribed and their accuracy was controlled by listening to them again.

In qualitative researches the process performed basically is to gather similar data within the frame of certain concepts (codes) and themes and to interpret them by organizing them in a form that reader can comprehend (Yıldırım and Şimşek, 2006, p.227). For this purpose, codes and themes were determined on the basis of the opinions of the students while content analysis was performed at the study. The obtained findings by organizing the codes and themes were presented as tables with the frequency value. In addition, samples from related students' opinions were given for better comprehension of codes and themes within the study. For the reliability of the study, after the transcription of the recorded interviews, it was codified independently by a different researcher, the results were compared and it was seen that compatible codings with each other were made. 


\section{Findings}

Data obtained at the end of the interviews made with students in the study group within the scope of the study was presented in the form of tables.

Table 4. The Analysis of the Answers Which Students Gave to the Question of "For what purpose you use mind maps?"

\begin{tabular}{|c|c|c|c|}
\hline Themes & Codes & f & Sample Expressions \\
\hline \multirow{7}{*}{ learning } & Interpreting what was learned & 28 & \multirow{15}{*}{$\begin{array}{l}\text { "I use it for envisaging the concepts which is hard to keep in } \\
\text { mind." } \\
\text { "Since we express mind map via symbols and pictures, we learn } \\
\text { hard subjects in a permanent and funny way by using both right } \\
\text { and left lobes of our brain." } \\
\text { "We may draw the subjects about the course with mind map. } \\
\text { Comparing to someone who takes note one under the other, } \\
\text { information can be written on one page rather than taking } \\
\text { notes on pages." } \\
\text { "I use mind map at subjects which I find them hard to } \\
\text { remember while I prepare for exam" } \\
\text { "We use mind map to easily remember certain parts of our } \\
\text { presentation" } \\
\text { "While the project is being prepared, we can show our project } \\
\text { gradually with mind map" } \\
\text { "It is a method that we may use in physicological support units } \\
\text { in order to recognize the individual in a better way." } \\
\text { "We can draw our targets with mind map while planning our } \\
\text { future." } \\
\text { "In the process of teaching class rules, a mind map which rules } \\
\text { were pictured awakes attention and it is effective especially in } \\
\text { small classrooms." }\end{array}$} \\
\hline & $\begin{array}{l}\text { Reinforcing what was learned and increasing the } \\
\text { permanence }\end{array}$ & 19 & \\
\hline & Preparing summary & 16 & \\
\hline & Note taking & 10 & \\
\hline & Preparing for exam & 4 & \\
\hline & Concretizing the abstract subjects & 3 & \\
\hline & Providing the concentration & 3 & \\
\hline \multirow{5}{*}{ planning } & Preparing presentation & 11 & \\
\hline & Preparing plan / project & 7 & \\
\hline & Using time effectively & 5 & \\
\hline & Brain storming & 3 & \\
\hline & Determining target & 2 & \\
\hline \multirow{3}{*}{$\begin{array}{c}\text { Social } \\
\text { features }\end{array}$} & Introducing ourselves or recognizing individuals & 9 & \\
\hline & Teaching rules to children & 2 & \\
\hline & Understanding the world of children & 2 & \\
\hline
\end{tabular}

As seen in Table 4, the answers given by students are collected under the themes of learning, planning and social features. It is determined that in the theme of "learning", students use mind maps mostly for the purpose of interpreting what was learned, reinforcing what was learned and increasing the permanence, preparing summary and note taking. It is determined that students apply for mind maps in the theme of "planning" for preparing presentation, preparing plan/project and using time effectively and in the theme of "planning" for introducing ourselves or recognizing individuals, teaching rules to children and understanding the world of children.

Table 5. The Analysis of the Answers Which Students Gave to the Question of "What are benefits provided by usage of mind maps?"

\begin{tabular}{|c|c|c|c|}
\hline Themes & Codes & f & Sample Expressions \\
\hline \multirow{7}{*}{ cognitive } & Ensures permanent learning. & 28 & \multirow{13}{*}{$\begin{array}{l}\text { "Page layout and colorful pens that we use ensures to be } \\
\text { permanent." } \\
\text { "Mind map is a method which we imprint information by using the } \\
\text { right and left lobes of our brain in opposition to memorizing." } \\
\text { "Mind map is giving you a key while recalling. It enables you to } \\
\text { open the door." } \\
\text { "Studying by preparing mind map enables to prevent us from note } \\
\text { extracting of } 15-20 \text { pages in vain." } \\
\text { "Since we codify each information in a way that it will be kept in our } \\
\text { mind, it becomes personal and it becomes easy to remember." } \\
\text { "Mind maps are like traffic rules. We understand what it is when we } \\
\text { see it." } \\
\text { "It is funny job to study with colors and visuals and so learning } \\
\text { becomes funny in a way." } \\
\text { "It is funny because we use visual elements more than writings and } \\
\text { we express the information we have learned with personal pictures } \\
\text { and writings } \\
\text { "While it was boring to take notes before, thanks to mind map it } \\
\text { became funnier and it ensured my brain to operate multifaceted." }\end{array}$} \\
\hline & $\begin{array}{c}\text { Ensures the usage of right and left lobes of brain } \\
\text { actively. }\end{array}$ & 17 & \\
\hline & Ensures meaningful and efficient learning. & 17 & \\
\hline & Facilitates remembrance. & 16 & \\
\hline & Ensures considering the subject as a whole. & 11 & \\
\hline & Ensures multi-dimensional thinking. & 4 & \\
\hline & Ensures envision of what was learned. & 4 & \\
\hline \multirow{2}{*}{ affective } & It is a funny activity. & 6 & \\
\hline & Increases interest, attention and motivation. & 3 & \\
\hline \multirow{4}{*}{$\begin{array}{l}\text { İndividual } \\
\text { features }\end{array}$} & $\begin{array}{l}\text { It is a practical form of presentation which is } \\
\text { prepared in a short time. }\end{array}$ & 14 & \\
\hline & It is personal. & 8 & \\
\hline & It improves creativity and imagination. & 8 & \\
\hline & Improves our visual perception. & 6 & \\
\hline
\end{tabular}

According to Table 5, the answers given by students are collected under the themes of cognitive, affective and individual features. Students stated in the theme of "cognitive", the benefits provided by mind map usage as ensuring of permanent learning, ensuring the right and left lobes of brain being active, facilitating remembrance, ensuring meaningful 
and efficient learning, ensuring considering the subject as an whole, ensuring multi-dimensional thinking, ensuring envision of what was learned. While students emphasized in the theme of "affective", the benefits provided by mind map usage as an activity which increases interest, attention and motivation, in the theme of "individual features" they expressed that it was personal, it improved creativity and imagination and our visual perception and it was a practical form of presentation which is prepared in a short time.

Table 6. The Analysis of the Answers Which Students Gave to the Question of "What are the constraints of using mind maps?"

\begin{tabular}{|c|c|c|c|}
\hline Themes & Codes & f & Sample Expressions \\
\hline \multirow{5}{*}{ individual } & Being hard for the brain. & 3 & \multirow{7}{*}{$\begin{array}{l}\text { "We push our brain harder while preparing mind map, since we use } \\
\text { right and left lobes of the brain actively." } \\
\text { "Others may not understand what we have told, since mind map is } \\
\text { personal." } \\
\text { "Codifying with symbols increase permanency but sometimes } \\
\text { forget a symbol which I was used in a mind map I have prepared } \\
\text { before." } \\
\text { "I cannot prepare my mind map as I wish when I do not have my } \\
\text { colourful pens with me." } \\
\text { "I sometimes cannot find the picture which I will use in my mind } \\
\text { map." }\end{array}$} \\
\hline & Since it is personal, being hard for others to understand. & 2 & \\
\hline & Forgetting the meanings attributed to some symbols. & 2 & \\
\hline & Not having a good skill of drawing. & 2 & \\
\hline & $\begin{array}{l}\text { The difficulty of finding the symbols related to the } \\
\text { subject. }\end{array}$ & 1 & \\
\hline \multirow[b]{2}{*}{ material } & Not having the colored pencils every time. & 5 & \\
\hline & Not finding the requested visuals every time. & 4 & \\
\hline
\end{tabular}

When table 6 is examined, the answers given by students are collected under the themes of individual and material. While students specify the constraints of using mind map in the theme of "individual" as being hard for the brain, being hard for others to understand since it is personal, forgetting the meanings attributed to some symbols, not having a good skill of drawing and the difficulty of finding the symbols related to the subject, they specified them in the theme of "material" as not having the colored pens every time and not finding the requested visuals every time.

Table 7. The Distribution of the Answers Which Students Gave to the Question of "How do you evaluate your development process at the subject of preparing mind map?"

\begin{tabular}{|l|l|l|}
\hline No & Expressions & f \\
\hline 1 & While using writings more, then I started to use visuals more. & 10 \\
\hline 2 & While considering with limited patterns before, later on I started to choose more different symbols and presentation forms. & 9 \\
\hline 3 & My drawing skill has improved. & 8 \\
\hline 4 & My imagination and creative thinking skill has improved. & 7 \\
\hline 5 & While using limited colors before, afterwards I started to use more different colors. & 7 \\
\hline 6 & While I prepare the mind maps I prepared primarily in a long time, then I started to prepare in a shorter time. & 7 \\
\hline 7 & Even I find it hard at the beginning; afterwards preparing mind map became funny. & 7 \\
\hline 8 & While I find it hard to choose the symbols related to the subjects before, later on I managed to decide easier. & 5 \\
\hline 9 & While I have difficulty in showing the details before, then I branched easier. & 5 \\
\hline 10 & While preparing in small sizes before, then I started to draw bigger mind maps encompassing the whole page. & 4 \\
\hline 11 & My multidimensional thinking skill has improved. & 4 \\
\hline
\end{tabular}

According to Table 7, while evaluating their development process at the subject of preparing mind map, students indicated that while they use writings more, then they started to use visuals more, while considering with limited patterns before, later on they started to choose more different symbols and presentation forms, their drawing skill, their imagination and creative thinking skill has improved, while using limited colors before, afterwards they started to use more different colors, while preparing the mind map in a long time, then they started to prepare in a shorter time, while finding it hard to choose the symbols before, later on they managed to decide easier, while having difficulty in showing the details before, then they branched easier.

\section{Conclusion, Discussion and Suggestions}

According to the findings acquired at this study which is aimed to determine the opinions of the university students related to usage of mind maps and their development processes in preparing the mind map, it was determined that students used mind maps mostly to interpret what was learned, to reinforce what was learned and increase the permanence, to prepare summary, to prepare presentation 
and to take notes.

Similar to these conclusions, also Aydın (2009), Çamlı (2009), Yetkiner (2011) and Aslan (2006) determined that usage of mind map technique ensured the information of the students to be permanent. These findings overlap with the opinions of Buzan and Buzan (2007) and consideration of Gelb (2002) that "Mind mapping ensures you to remember by integrating what was told in books and courses to your brain friendly." For learning to become effective and permanent it is required that learning and recording information process become effective. Beside process of recording the information vary from person to person, the being personal aspect of mind maps increases its practicability. While individual prepare mind map in line with his/her own preliminary information, interests and needs, he/she becomes active in the learning process by constructing his/her information.

Students stated the positive aspects of mind map mostly as ensuring of permanent learning, ensuring the right and left lobes of brain to become active, ensuring meaningful and efficient learning, facilitating remembrance, being a practical form of presentation which is prepared in a short time, being personal, being a funny activity which increases interest, attention and motivation. These findings overlap with the opinion of Öztürk (2005, p.176-177) that "In this system which is converted to a visual feast totally by means of colored pens information lasts more in memory and recalled faster." Because colors, images and keywords namely three basic components of mind maps, are adopted much easier than sentences by brain (Gelb, 2002).

Similar to this conclusions; Steyn and Boer (1998), in their studies reached to the conclusion that students enjoy using mind map technique and remember easily what they learned with mind map technique; Goodnough and Woods (2002), in their studies reached to the conclusion that students express positive opinion about mind mapping, find this technique funny and interesting and enjoy using it.

Students remarked negative aspects of preparing mind map as being hard for the brain, being hard for others to understand since it is personal, forgetting the meanings attributed to some symbols, not having a good skill of drawing, not finding the colored pens and the requested visuals every time.

While evaluating their development processes at the subject of preparing mind map, students indicated that they started to use visuals more, they started to choose different symbols and presentation forms, their drawing, imagination and creative thinking skill has improved, they started to use different colors, they prepared in a shorter time, they decided symbols easier and they branched the details easier.

While preparing mind map, individuals constructing what they have learned in their minds by using words and symbols and also by linking up ensures learning become individual, meaningful and efficient and thus facilitates what has learned to be remembered. From this aspect, as seen in the conclusion of the study there are so many learning outcomes that preparing of mind map ensures. On that sense, mind maps may be taught to students at different levels and it can be ensured that they use it at their lessons with different purposes such as note-taking, summarizing, evaluating, determining their targets and expressing themselves. Hence, while ensuring students to use both lobes of their brain actively, their properties such as creative thinking, improving imagination, developing holistic view may be developed as well. In addition, studying with a system different from the classical studying form would enable learning process to become funny. On the other hand, based on technology being used quite effectively nowadays, mind maps may be prepared by means of computer.

\section{REFERENCES}

[1] Abi-El-Mona, I. \& Abd-El-Khalick, F. (2008). The influence of mind mapping on eighth graders' science achievement. School Science and Mathematics, 108(7), 298-312.

[2] Anderson, J. V. (1993). Mind mapping: A tool for creative thinking. Business Horizons, 13(2), 41-46.

[3] Aslan, A. (2006). İlköğretim Okulu 4. Sinıf Öğrencilerinin Bilgilendirici Metinleri Anlama, Özetleme ve Hatırlama Becerileri Üzerinde Zihin Haritalarının Etkisi. Unpublished Master's Thesis, Gazi University, Institute of Educational Sciences, Ankara.

[4] Aydın, G. (2009). Zihin Haritalama Tekniğinin Dinleneni Anlamaya Etkisi. Unpublished Master's Thesis, Atatürk University, Institute of Social Sciences, Erzurum.

[5] Brinkmann, A. (2003). Graphical Knowledge Display-Mind Mapping and Concept Mapping as Efficient Tools in Mathematics Education. Mathematics Education Review, 16, $35-48$.

[6] Buzan, T. (2005). Mind map handbook. Great Britain: Thorsons.

[7] Buzan, T. (2009a). Akıl Haritaları: Yaratıcılı̆̆ınızı Harekete Geçirin ve Dönüştürün. Hakan Öneş (Ed.), İstanbul: Boyut.

[8] Buzan, T. (2009b). Muhteşem Hafızanızla Tanışın. Hakan Öneş (Ed.), İstanbul: Boyut.

[9] Buzan, T. \& Buzan, B. (2007). The Mind Map Book. Edinburg, England: BBC Active.

[10] Bütüner, S. Ö. (2006). Açılar ve üçgenler konusunun ilköğretim 7. sinıf ögrencilerine $v$ diyagramlar ve zihin haritaları kullanılarak ögretimi. Unpublished Master's Thesis, Balıkesir University, Institute of Science, Balıkesir.

[11] Cohen, L. \& Manion, L. (1994). Research methods in education (4th Ed.). London: Routledge.

[12] Cryer, P. (2006). Research student's guide to success. Buckingham, GBR: Open University Press. 
[13] Camlı, H. (2009). Bilgisayar Destekli Zihin Haritalama Tekniğinin İlkögretim 5. Sinıf Öğrencilerinin Akademik Başarllarına, Fene ve Bilgisayara Yönelik Tutumlarına Etkisi. Unpublished Master's Thesis, Ege University, Institute of Science, İzmir.

[14] Gelb, M. J. (2002). Düşünmenin Tam Zamanı (Trans. Taylan Bilgiç). İstanbul: Arion.

[15] Goodnough, K. \& Long, R. (2006). Mind mapping as a flexible assessment tool, in M. McMahon, P. Simmons, R. Sommers, D. DeBaets \& F. Crawley (ed.), Assessment in Science: Practical Experiences and Education Research (pp. 219-228). Arlington, VA, USA: National Science Teachers Association Press.

[16] Goodnough, K. \& Woods, R. (2002). Student and teacher perceptions of mind mapping: A middle school case study. The Annual Meeting of the American Educational Research Association, New Orleans, LA (1-5 April).

[17] Healy, J. M. (1997). Çocuğunuzun Gelişen Akli: Doğumdan Ergenliğe Ögrenme ve Beyin Gelişimi. İstanbul: Enka.

[18] Holland, B., Holland, L. \& Davies. J. (2004). An Investigation Into The Concept of Mind Mapping and The Use of Mind Mapping Software to Support and Improve Student Academic Performance. (Ed. H. Gale) Learning and Teaching Projects 2003/2004. University of Wolverhampton.

[19] Jones, S. (1985). Depth interviewing. R. Walker (Ed.) Applied qualitative research (pp. 46-55). England: Gower Publishing Company.

[20] Karasar, N. (2004). Bilimsel Araştırma Yöntemi. Ankara: Nobel.

[21] Kokotovich, V. (2008). Problem analysis and thinking tools: An empirical study of non-hierarchical mind mapping. Design Studies, 29 (1), 49-69.

[22] Margulies, N. (1991). Mapping inner space. Tucson: Zephyr Press.

[23] Mento, A. J., Martinelli, P. \&Jones, R. M. (1999). Mind mapping in executive education: Applications and outcomes. Journal of Management Development. 18(4). 390-416. http://dx.doi.org/10.1108/02621719910265577
[24] Michalko, M. (2001). Cracking Creativity: The Secrets of Creative Genius, Berkley: California Ten Speed Press.

[25] Mento, A. J., Martinelli, P. J. \& Raymond M. (1999). Mind mapping in executive education: Application and outcomes, The Journal of Management Development, 18(4), 390-407.

[26] Öztürk, H. (2005). Öğrenmenin Büyüsü. İstanbul: Hayat.

[27] Patton, Q. M. (1987). How to Use Qualitative Methods in Evaluation. London: Sage Pub.

[28] Steyn, T. \& Boer, A. (1998) Mind mapping as a study tool for underprepared students in mathematics and science, South African Journal of Ethnology, 21(3), 1-11

[29] Tavukçuoğlu, C. (2002). Bilimsel Araştırma Yöntemleri ve Proje Hazırlama, Değerlendirme Kılavuzu. Ankara: Kara Harp Okulu Basım Evi.

[30] Tetzeli, R. (1992). Mind mapping: A new way to think on paper. Fortune, 19(3). Retrived January 13, 2010, from http://money.cnn.com/magazines/fortune/fortune archive/1992/11/16/77157/index.htm

[31] Townsend, R. (1998). Öğrenme Zenginliği. İstanbul: Sistem.

[32] Wycoff, J. (1991). Mind mapping: your personal guide to exploring creativity and problem solving. New York: Berkley Books.

[33] Wickramasinghe, A., Widanapathirana, N., Kuruppu, O., Liyanage, I. \& Karunathilake, I. (2008). Effectiveness of mind maps as a learning tool for medical students. South East Asian Journal of Medical Education, 1(1), 30-32.

[34] Yetkiner, A. (2011). İlköğretimde İngilizce Öğretiminde Zihin Haritası Kullanımının Öğrencilerin Akademik Başarılarına, Tutumlarına ve Kalıcılı̆̆a Etkisi. Unpublished Master's Thesis, Frrat University, Institute of Educational Sciences, Elazığ.

[35] Yıldırım, A. \& Şimşek, H. (2006). Sosyal Bilimlerde Nitel Araştırma Yöntemleri. Ankara: Seçkin.

[36] Zhao, Y. (2003). The use of a constructivist teaching model in environmental science at Beijing University. The China Papers, 2, 78-83. 